\title{
Effect of different doses of acid milk serum on growth in rice culture and on soil chemical attributes
}

Bruno Manoel Rezende de Melo ${ }^{1}$

Douglas Goulart Castro

Tácio Peres da Silva ${ }^{3}$

Antonio Rosário Neto 4

Marco Renan Félix ${ }^{5}$

Flávia Barbosa Silva Botelho ${ }^{6}$

\section{Abstract}

The culture of rice has great potential to constitute the production systems of annual perennial crops, mainly in small properties. This allows this system to integrate with other activities such as the dairy industry, taking advantage of the milk by-product, reducing the environmental liability for disposal in the environment. Therefore, the objective was to evaluate the growth and productivity of rice grains under different doses of acid milk serum $\left(0 \mathrm{~m}^{3} \mathrm{ha}^{-1}, 5 \mathrm{~m}^{3} \mathrm{ha}^{-1}, 10 \mathrm{~m}^{3} \mathrm{ha}^{-1}, 20 \mathrm{~m}^{3} \mathrm{ha}^{-1}, 50 \mathrm{~m}^{3} \mathrm{ha}^{-1}\right.$, $100 \mathrm{~m}^{3} \mathrm{ha}^{-1}$, and $150 \mathrm{~m}^{3} \mathrm{ha}^{-1}$ ), in soil applications with monitoring of fertility and electrical conductivity levels. The rice was sown in the UFLA experimental field, using the BRSMG Esmeralda lineage. Seven different doses were used, divided into two applications via soil. No cover fertilization was carried out. Yield and crop growth variables were determined by monitoring the nutrient content in the soil profile and the sodification and salinization capacity of the residue. It was found that the increase in serum doses increased the electrical conductivity and the percentage of exchangeable sodium by 1.75 and 7.75 compared to the control, but did not cause the process of sodification and salinization of the soil. As acid milk serum is a significant source of potassium, its use in the soil did not promote significant grain yield. It was concluded that the acid milk serum in the doses used did not cause sodification or salinization of the soil. This residue is the safe dose that can be used as potassium and nitrogen. The acid milk serum in the tested conditions did not increase the growth of the culture.

Keywords: Fertility. Oryza sativa. Organic waste. Salinization. Sodium.

\section{Introduction}

The culture of rice shows a great importance in the supply of food consumed by a good part of the world population, besides, it has the potential to constitute the systems of agricultural production, both annual crops and perennial crops in intercropping, mainly in small properties, also integrating other activities such as dairy farming and the dairy industry.

1 Instituto Federal de Educação, Ciência e Tecnologia do Sul de Minas Gerais. Doutor em Fitotecnia/Técnico administrativo. bruno.melo@ifsuldeminas.edu.br

2 Universidade Federal de Uberlândia, Pós-doutorando. douglasgoulartcastro@gmail.com

3 Universidade Federal de Lavras, Doutor em Fitotecnia. tacioagro@gmail.com

4 Universidade Federal de Lavras, Doutorando em Fitotecnia, rosário.agronomia@gmail.com

5 Universidade Federal de Viçosa, Doutorando em Genética e Melhoramento de Plantas, mrenan05@hotmail.com

6 Universidade Federal de Lavras, Professora Adjunta do Departamento de Agricultura. flaviabotelho@dag.ufla.br 
To take advantage of the integration of these activities, the use of acid milk serum can be used to stimulate the growth and productivity of the rice culture, thus reducing its disposal and consequently contamination of the environment.

The acid milk serum is a residue from the dairy industry, which depending on the production process can give rise to two by-products: acid milk serum, which comes from the processing of caseins that are coagulated in an acidic medium while sweet is coagulated in an enzymatic medium (ALVES et al., 2014).

In Brazil, in 2017, the production of acid milk serum was estimated at 2.7 million tons (BRASIL, 2017). Due to a large amount of this residue, industries have used acid milk serum in several production processes, such as the production of new food products and medicines (ZAVAREZE; MORAES; SALAS-MELLADO, 2010).

However, this process is hampered by the fact that acid milk serum is a perishable product, limiting its storage for a prolonged period, associated with the fact that, for the construction of these facilities, high investments are necessary, becoming a practice of low viability for small entrepreneurs. Thus, most of the serum is still discarded (SILVA et al., 2018; SIQUEIRA; MACHADO; STAMFORD, 2013).

This residue, depending on the chemical composition with a high concentration of organic matter and nutrients, can be applied as an agricultural fertilizer, which allows farmers to reduce their dependence on external inputs while minimizing production costs (ALENCAR et al., 2012). On the other hand, when applied in higher doses and depending on the sodium content, this residue can be a contaminant of water and soil, which causes a great environmental liability.

To increase the safety of the use of this residue in the soil, monitoring must take place depending on the electrical conductivity and sodium adsorption, since this biofertilizer can cause sodification of the medium and clay dispersion causing the soil to become denser (FRENKEL; GOERTZEN; RHOADES, 1978).

Some authors are already studying the technical feasibility of using acid milk serum in agriculture, given the ability to supply nutrients. Mantovani et al. (2015) concluded that the supply of acid milk serum increases the levels of available $P$ and $K$, increasing the dry matter production of corn plants. It is worth mentioning that doses up to $200 \mathrm{~m}^{3} \mathrm{ha}^{-1}$ should be used in association with mineral fertilization.

Bearing in mind that techniques for improvement and greater productivity reach can be acquired with the application of acid milk serum in agriculture, given the above, the objective was to evaluate the growth and productivity of rice under different doses of acid milk serum, in applications in the soil, monitoring fertility levels, the electrical conductivity of the soil and classifying the serum as to the potential for sodicity and salinity.

\section{Material and methods}

The experiment was carried out in the agricultural year 2017/2018, with different doses of acid milk serum, being carried out at the experimental farm of the Center for Scientific, Technological Development in Agriculture at UFLA - Muquém Farm, located at $910 \mathrm{~m}$ altitude at $21^{\circ} 15^{\prime} \mathrm{S}$ latitude, and $45^{\circ} 00^{\prime} \mathrm{W}$ longitude coordinates, in Red-Yellow Latosol. Soil sampling from the experimental area was carried out to determine the chemical and physical parameters of the soil, and the samples were sent to the UFLA soil analysis laboratory, with analysis carried out according to the method described by Embrapa (1997). 
Sowing was carried out in a no-tillage system. The cultivar used was BRS Esmeralda, with a density of 80 linear meter seeds with a distance of $0.35 \mathrm{~m}$ between rows.

Planting fertilization was carried out, according to the recommendations of Sousa, Lobato, and Rein (2004) and Villar (2007), for expected productivity of $4 \mathrm{t} \mathrm{ha}^{-1}$, applying $200 \mathrm{~kg} \mathrm{ha}^{-1}$ from 04-14-08 on planting, not performing the cover fertilization. Sowing and harvesting took place respectively in November 2017 and April 2018.

The experiment was conducted in a randomized block design (RBD), with plots consisting of three lines three meters long and 0.35 meters between rows, in which the central line was the useful plot. The trial consisted of seven doses of acid milk serum $\left(0 \mathrm{~m}^{3} \mathrm{ha}^{-1}, 5 \mathrm{~m}^{3} \mathrm{ha}^{-1}, 10 \mathrm{~m}^{3} \mathrm{ha}^{-1}, 20 \mathrm{~m}^{3} \mathrm{ha}^{-1}\right.$, $50 \mathrm{~m}^{3} \mathrm{ha}^{-1}, 100 \mathrm{~m}^{3} \mathrm{ha}^{-1}$, and $150 \mathrm{~m}^{3}$ ha $^{-1}$ ) with 4 repetitions with half of these doses applied 20 days and 40 days after emergence, using watering cans. The acid milk serum was provided by the company Verde Campo in the city of Lavras and collected the day before each application. A sample of acid milk serum was sent to the IBRA laboratory to determine the levels of macro and micronutrients, $\mathrm{pH}$, electrical conductivity, and density.

After each application, sprinkler irrigation was performed to prevent the action of the results from reflecting the water present in the residue. For the management of weeds, the herbicides were used: Pendimethalin in pre-emergence and Metsulfuron-methyl in post-emergence, followed by two manual weedings.

In each treatment of acid milk serum, on the day after the crop was harvested, four sub-samples of soil with an auger for the depth of $0 \mathrm{~cm}$ to $20 \mathrm{~cm}$ were collected, one in each plot, to evaluate the contents of $\mathrm{K}, \mathrm{Na}$, sum of bases (SB), cation exchange capacity ( $\mathrm{T}$ ), $\mathrm{pH}$, electrical conductivity (EC), exchangeable sodium percentage (PST) and sodium adsorption ratio (SAR), according to methodologies described by Embrapa (1997): with the concentrations sodium, calcium, and magnesium expressed in $\mathrm{cmol}_{\mathrm{c}} \mathrm{dm}^{-3}$.

The salinity and sodicity of acid milk serum were classified based on the values of electrical conductivity and SAR, respectively (RICHARDS, 1954).

The chemical parameters of the soil were analyzed by Pearson's linear correlation matrix, aiming to perform simple linear correlations ( $p<0.05$ and $p<0.01$ ), through the genes program (CRUZ, 2013) for $\mathrm{K}^{+}$contents, $\mathrm{Na}^{+}, \mathrm{SB}, \mathrm{pH}, \mathrm{T}, \mathrm{EC}, \mathrm{SAR}$, and PST.

The phytotechnical characters evaluated in the useful area were:

- Leaf area of eight plants, measuring the length and largest width of the flag leaf, after complete expansion, multiplied by the correction index of 0.74 calculating the final leaf area in $\mathrm{m}^{2} \mathrm{AF}=\mathrm{C}$ * $\mathrm{L}$ * 0.74 (TIVET et al., 2001);

- Height of five plants per plot (distance from the soil surface to the apex of the flag leaf) in centimeters;

- Total chlorophyll index: performed at the flowering stage on the flag leaf, in two readings per leaf, using the electronic chlorofiLOG meter, model CFL 1030;

- Severity of diseases: evaluating blast, neck blast, grain stain, scald, brown spot, with the analysis at the flowering stage and one week before harvest, using the International Rice Research Institute scale (IRRI, 1996), in which: note 0 without impact; grade 1 less than $5 \%$ of infected leaves; grade 3 from $5 \%$ to $10 \%$ of infected leaves; grade 5 between $11 \%$ and $25 \%$ of infected leaves; grade 7 between $26 \%$ and $50 \%$ of infected leaves and grade 9 greater than $50 \%$ of infected leaves;

- Grain productivity: data in grams per plot, adjusted for $\mathrm{kg} \mathrm{ha}^{-1}$; 
- Weight of 1,000 grains: the weight of 100 grains, repeated eight times, with the average obtained multiplied by 10 ;

- Income: percentage of processed rice (clean), resulting from the processing of paddy rice;

- Yield: percentage of whole grains resulting from the benefit of rice grains;

- Dry weight of the aerial part of all plants in the radius of 0.5 meters / linear.

After data collection, analysis of variance was performed and in the presence of a significant result ( $p<0.05$ ), the polynomial model was used for the effect of doses of the input. The criterion for choosing the model was the significance by the $F$ test at $5 \%$ probability that it had the highest value of the significant coefficient of determination ( $r 2)$. Statistical analysis was performed using the Sisvar software (FERREIRA, 2011). The normality of the data was verified according to the Lilliefors test (CAMPOS, 1983), through the Genes program (CRUZ, 2013). The data that did not present a normal distribution were transformed by the equation $(x+1)^{0,5}$.

\section{Results and discussion}

Nitrogen and potassium are the nutrients in greater quantity in acid milk serum (TABLE 1), so the application recommendation can be made depending on these nutrients. Attention should be paid to the application of this residue mainly to soils with lower cation exchange capacity since there is a risk of leaching potassium (RAIJ, 2011) and nitrogen in the form of nitrate since these are supplied in liquid form.

Table 2 shows the results of the chemical and physical analysis of the soil before the installation of the experiment. It appears that the levels of potassium and phosphorus are above the critical level. However, there is a divergence between the results of the analysis before the experiment and after the experiment. The analysis of Table 2 was carried out in the total area, and in the second analysis (TABLE 3), it was carried out promptly of the plots, and these differences are not only the results of nutrient exports and possible leaching that may have occurred but probably due to the spatial and temporal variability of chemical and physical attributes in the soil.

Table 1 - Chemical and density parameters of acid milk serum, 2020.

\begin{tabular}{|c|c|c|c|c|c|c|c|}
\hline$N(g)$ & $P(g)$ & K (g) & $\mathrm{Ca}(\mathrm{g})$ & $\mathrm{Mg}(\mathrm{g})$ & $S(g)$ & $\mathrm{B}(\mathrm{mg})$ & $\mathrm{Cu}$ (mg) \\
\hline 3,7 & 0,8 & 1,5 & 0,3 & 0,1 & 0,3 & 0 & 0 \\
\hline $\mathrm{Fe}(\mathrm{mg})$ & $\mathrm{Mn}$ (mg) & $\mathrm{Na}$ (mg) & $\mathrm{Zn}$ (mg) & Mo (mg) & CE dS m-1 & $\mathrm{pH}$ & $\rho^{*} \mathrm{~g} \mathrm{mL-1}$ \\
\hline 269,00 & 0 & 730,15 & 3,44 & 260,66 & 0,16 & 3,5 & 1,04 \\
\hline
\end{tabular}

*Especific mass

Source: Elaborated by Bruno Manoel Rezende de Melo (2020). 
Table 2 - Chemical and physical analysis of the soil, from Experimental Farm, 2020.

\begin{tabular}{|c|c|c|c|c|c|c|c|}
\hline \multirow{2}{*}{$\mathrm{pH}$} & $\mathrm{K}$ & $\mathbf{P}$ & $\mathrm{Na}$ & $\mathrm{Ca}$ & Mg & Al & $\mathrm{H}+\mathrm{Al}$ \\
\hline & \multicolumn{3}{|c|}{ - } & \multicolumn{3}{|c|}{$-\mathrm{cmol}_{\mathrm{c}} \mathrm{dm}^{-3}$} & $\mathrm{cmol}_{\mathrm{c}} \mathrm{dm}^{-}$ \\
\hline 5,8 & 155,62 & 42,62 & - & 3,01 & 0,84 & 0,11 & 3,82 \\
\hline SB & $\mathbf{t}$ & $\mathbf{T}$ & V & m & MO & P-rem & $\mathrm{Zn}$ \\
\hline \multicolumn{3}{|c|}{$-\mathrm{cmol}_{\mathrm{c}} \mathrm{dm}^{-3}$} & \multicolumn{2}{|c|}{--------\%-------. } & dag $\mathrm{kg}^{-1}$ & $\mathrm{mg} \mathrm{L}^{-1}$ & $\mathrm{ml} \mathrm{dm}^{-3}$ \\
\hline 4,25 & 4,36 & 8,07 & 52,65 & 2,52 & 2,37 & 28,26 & 4,88 \\
\hline $\mathrm{Fe}$ & Mn & $\mathrm{Cu}$ & B & $\mathbf{S}$ & Argila & Silte & Areia \\
\hline \multicolumn{5}{|c|}{ 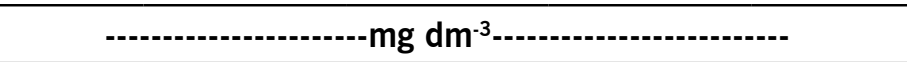 } & \multicolumn{3}{|c|}{ - } \\
\hline 53,52 & 14,40 & 0,25 & 0,03 & 7,19 & 58 & 5 & 39 \\
\hline
\end{tabular}

Source: Elaborated by Bruno Manoel Rezende de Melo (2020).

The $\mathrm{T}$ and $\mathrm{pH}$ values in the soil, after the application of the highest dose of acid milk serum, were lower than the 0 dose of the residue (TABLE 3). Probably, this reduction does not occur linearly in the applied doses, given that these levels before application are not homogeneous in soils, and may present great spatial variability. In pH tests, the increase in soil acidity was already expected, considering that the residue itself is a proton donor (TABLE 3).

Table 3 - Soil contents of potassium, sodium, sum of bases (SB), cation exchange capacity ( $T$ ), $\mathrm{pH}$, electrical conductivity (EC), percentage of sodium in CTC (PST), and sodium adsorption ratio (SAR), as of acid milk serum doses, Lavras, MG, 2020.

\begin{tabular}{ccccccccc}
\hline Doses & $\mathbf{K}$ & $\mathbf{N a}$ & $\mathbf{S B}$ & $\mathbf{T}$ & $\mathbf{p H}$ & $\mathbf{E C}$ & $\mathbf{P S T}$ & SAR \\
\hline 0 & 75,68 & 0,007 & 5,23 & 8,03 & 6,3 & 0,04 & 0,08 & 0,004 \\
5 & 78,64 & 0,021 & 5,25 & 7,76 & 6,5 & 0,04 & 0,27 & 0,013 \\
10 & 79,96 & 0,021 & 4,28 & 8,15 & 5,9 & 0,04 & 0,25 & 0,015 \\
20 & 91,15 & 0,021 & 4,85 & 7,95 & 6,1 & 0,05 & 0,26 & 0,014 \\
50 & 80,06 & 0,021 & 4,12 & 7,94 & 5,7 & 0,05 & 0,26 & 0,015 \\
100 & 104,07 & 0,053 & 4,40 & 7,64 & 6,0 & 0,06 & 0,70 & 0,037 \\
\hline
\end{tabular}

Source: Elaborated by Bruno Manoel Rezende de Melo (2020).

The application of different doses of acid milk serum promoted a significant increase in $\mathrm{K}$, providing a positive linear correlation with EC, PST, and SAR (TABLES 3 and 4). These results provide important technical support since they allow to suggest the application of these residues as a source of the mentioned nutrients. However, this recommendation should be made with caution, considering that this practice can cause an increase in electrical conductivity and sodium levels in the soil.

For the relationship between $\mathrm{Na}, \mathrm{SB}$, and T (TABLE 4), even if the correlations were not significant, what is observed is that with the increase in sodium levels there is a reduction in the sum of bases and $\mathrm{T}$ (TABLE 3), probably due to the mass-action law displacing the bases of the $T$, this being a problem of greater magnitude mainly for low soils T. Melo et al. (2006) carrying out work with manipueira application simulation warned about the dangers contamination of groundwater by potassium, calcium, sodium, and magnesium by applying this residue to medium to sandy and low T soils. 
(Continuation)

Table 4 - Correlation matrix for soil chemical parameters of potassium, sodium, sum of bases (SB), cation exchange capacity $(\mathrm{T}), \mathrm{pH}$, electrical conductivity (EC), percentage of sodium in CTC (PST) and sodium adsorption ratio (SAR), and acid milk serum doses, 2020.

\begin{tabular}{ccccccccc}
\hline & $\mathbf{K}$ & $\mathbf{N a}$ & $\mathbf{S B}$ & $\mathbf{T}$ & $\mathbf{p H}$ & $\mathbf{E C}$ & $\mathbf{P S T}$ & SAR \\
\hline Doses & $0,92^{* *}$ & $0,89^{* *}$ & $-0,30$ & $-0,46$ & $-0,17$ & $0,97^{* *}$ & $0,88^{*}$ & 0,91 \\
$\mathrm{~K}$ & - & $0,84^{*}$ & $-0,23$ & $-0,43$ & $-0,08$ & $0,94^{* *}$ & $0,82^{* *}$ & $0,83^{* *}$ \\
$\mathrm{Na}$ & - & - & $-0,42$ & $-0,69$ & $-0,20$ & $0,87^{*}$ & $0,99 * *$ & $0,99^{* *}$ \\
$\mathrm{SB}$ & - & - & - & $-0,09$ & $0,94^{* *}$ &,- 039 & $-0,40$ & $-0,47$ \\
\hline T & - & - & - & - & $-0,26$ & $-0,52$ & $-0,72$ & $-0,66$ \\
PH & - & - & - & - & - & $-0,28$ & $-0,18$ & $-0,26$ \\
CE & - & - & - & - & - & - & $0,86^{*}$ & $0,87^{*}$ \\
PST & - & - & - & - & - & - & - & $0,99 * *$ \\
\hline
\end{tabular}

* significant at $1.0 \%$ and ** $5.0 \%$ respectively.

Source: Elaborated by Bruno Manoel Rezende de Melo (2020).

Even though the methodology used in the present work employs the use of serum in only two applications, the increase in these doses promoted an increase in the levels of EC, PST, and SAR, presenting a positive and significant correlation (TABLE 4); however, it is not enough to cause salinization or soil sodification in any of the doses.

For these problems to occur, the electrical conductivity value must be greater than $4 \mathrm{dS} \mathrm{m}^{-1}$ and PST must be greater than $15 \%$ in the soil (EMBRAPA, 2013), therefore, this content must be monitored to prevent sodification processes and salinization occur.

Considering that these doses used did not provoke a process of salinization or sodification, it is noteworthy that the highest dose of serum raised the levels of $\mathrm{K}, \mathrm{Na}, \mathrm{EC}, \mathrm{PST}$, and SAR respectively by $1.78 ; 7.0 ; 1.75 ; 7.75$, and 8.5 times when compared to the control (TABLE 3 ).

As for the electrical conductivity of the effluent, it found $0.16 \mathrm{dS} \mathrm{m} \mathrm{m}^{-1}$ and SAR of $2.94 \mathrm{cmol}_{\mathrm{c}}$ $\mathrm{dm}^{-3}$, classifying this as C1S4, corresponding to the risk of low salinity, causing no problems for the soil and crops, it can be used in most crops, however, for SAR it finds a very high content which makes its use for irrigation impossible (RICHARDS, 1954). This information imposes restrictive implications on the use of serum, as noted in Tables 3 and 4 , as sodium increases, electrical conductivity, SAR, and PST increase, limiting its use in higher doses in fertigation.

Homem et al. (2012) observed that the use of effluents from animal farms is not limited in use, however, the entire process must be monitored, as over time there may be an accumulation of compounds in the soil solution, promoting dispersion of the soil. Matos, Almeida Neto and Matos (2014) studying the physical, chemical, and mineralogical characteristics of three soils (Red -Yellow Latosol, Red Latosol, and a Red Argisol), concluded that they can receive waters with SAR and EC in an expressive way without suffering sodification, as long as the EC is not low.

For phytotechnical traits, there was no significant difference between the procedures (TABLE 5). The lack of significance for the increase and the maximum variation may be associated with other factors such as nutritional imbalances since the serum in the highest dose increased the potentiometer and sum of bases in the soil (Table 3), included in the system; the soil at the highest dose of $555 \mathrm{~kg} \mathrm{ha}^{-1}, 225 \mathrm{~kg} \mathrm{ha}^{-1}, 45 \mathrm{~kg} \mathrm{ha}^{-1}, 15 \mathrm{~kg} \mathrm{ha}^{-1}, 45 \mathrm{~kg} \mathrm{ha}^{-1}$, respectively, of $\mathrm{N}, \mathrm{K}, \mathrm{Ca}, \mathrm{Mg}$ and S.

As the potentiometer content in the soil was above the critical level in the installation of the experiment (TABLE 2), as the applications of these doses are rarely affected in the growth and 
reproduction of the culture, because in this condition the increments are decreasing, in addition to the possible imbalance with calcium and magnesium. This can be registered with gain that went from $2881 \mathrm{~kg} \mathrm{ha}^{-1}$ in the lowest dose to $3669 \mathrm{~kg} \mathrm{ha}^{-1}$ in the highest dose, with a gain of only $788 \mathrm{~kg}$, that is, an application of 225 times the amount of potassium in the largest dose concerning the lowest dose results in a gain of only 1.27 times.

Table 5 - Summary of Analysis of Variance for acid milk serum doses in the 2017/2018 agricultural year, involving leaf area, the weight of 1,000 grains height, chlorophyll index, height, dry weight, income, grain yield, and productivity, Lavras, MG, 2020.

\begin{tabular}{cccccccccc}
\hline SV & DF $^{1}$ & LA $^{2}$ & $\mathbf{W}^{3}$ & Chlo $^{4}$ & $\mathbf{H}^{5}$ & $\mathbf{D W}^{6}$ & $\mathbf{I}^{\mathbf{7}}$ & $\mathbf{Y}^{\mathbf{8}}$ & Prod $^{{ }^{9}}$ \\
\hline Doses & 6 & 0,15 & 0,09 & 0,82 & 0,22 & 0,11 & 0,62 & 0,99 & 0,19 \\
Blocks & 3 & 0,47 & 0,00 & 0,00 & 0,46 & 0,61 & 0,49 & 0,92 & 0,91 \\
\hline CV(\%) & - & 9,2 & 4,75 & 8,97 & 5,09 & 30,37 & 4,87 & 9,31 & 29,25 \\
\hline
\end{tabular}

${ }^{1}$ Degree of freedom, ${ }^{2}$ Leaf area, ${ }^{3}$ Weight of 1,000 grains, ${ }^{4}$ Chlorophyll, ${ }^{5}$ Height, ${ }^{6}$ Dry weight, ${ }^{7}$ Income, ${ }^{8}$ Yield, ${ }^{9}$ Productivity.

Source: Elaborated by Bruno Manoel Rezende de Melo (2020).

Therefore, acid milk serum, in all doses evaluated, can be used as a safe source to increase the levels of nutrients without negatively interfering with the chemical and physical components of the soil, as long as the doses to be applied are in line with the levels of the soil and need for culture.

This lack of significant response on productivity and the other variables may have occurred due to the phenological stage used to apply the serum, with similar results being verified in other works with the application of fertilizers. Dias, Silva and Maia (2010) observed in their research that the treatments showed different behaviors, although with significant results only for the nitrogen effect with $105 \mathrm{~kg} \mathrm{ha}^{-1}$ applied in isolation, at the beginning of tillering and in floral differentiation, and interactions with doses of NP, NK, PK, and NPK did not influence productivity.

Mantovani et al. (2015) found that serum doses of $200 \mathrm{~m}^{3}$ ha-1 were not sufficient to increase the nutritional requirement of corn, which corroborates part of our results, since the highest dose of serum applied in this study was less than that cited by these authors. The authors also point out that this dose of the residue caused limitations in the growth of the crop, not meeting the nutritional needs of corn.

More expressive results with serum were verified by Morrill et al. (2012), who developed works with the culture of millet and sorghum without application of fertilizers, using sweet acid milk serum in installment applications. The authors concluded that the largest accumulation of dry matter was with $370 \mathrm{~m}^{3} \mathrm{ha}^{-1}$ of the residue, and from these doses, there was phytotoxicity of the cultures. The application occurred before sowing and 20 days after emergence. These authors point out that the methodology used is more adequate to stabilize organic matter, differing from the methodology proposed in this work.

\section{Conclusions}

The acid milk serum whey, in the doses used, did not promote sodification or salinization of the soil.

This residue in the tested doses can be used as a source of $\mathrm{K}$ and $\mathrm{N}$, with limitations in higher doses due to the risk of soil sodification. 
The acid milk serum, in the conditions of the study, did not increase the growth and productivity of the culture.

\section{Acknowledgments}

The authors express their thanks to the Federal Institute of Education, Science and Technology of the South of Minas Gerais (IFSULDEMINAS), for the support granted during the conduct of the work, to the Research Support Foundation of the state of Minas Gerais (FAPEMIG), to National Council of Scientific and Technological Development (CNPq), to Coordination for the Improvement of Higher Education Personnel (CAPES), for the granting of scientific initiation, masters and doctoral scholarships.

\section{Doses de soro ácido de leite no crescimento na cultura do arroz e seus efeitos nos parâmetros químicos do solo}

A cultura do arroz tem grande potencial para constituir os sistemas de produção de lavouras perenes anuais, principalmente em pequenas propriedades. Isso permite que esse sistema se integre a outras atividades como a indústria de laticínios, aproveitando o subproduto do leite, reduzindo o passivo ambiental de descarte no meio ambiente. Portanto, objetivou-se avaliar o crescimento e a produtividade de grãos de arroz sob diferentes doses de soro de leite $(0,5,10,20,50,100$ e $150 \mathrm{~m}^{3} \mathrm{ha}^{-1}$ ), em aplicações no solo com monitoramento de níveis de fertilidade e condutividade elétrica. $O$ arroz foi semeado no campo experimental da UFLA, utilizando a linhagem BRSMG Esmeralda. Foram utilizadas sete diferentes doses, divididas em duas aplicações via solo. Não foi realizada fertilização de cobertura. As variáveis de rendimento e crescimento da cultura foram determinadas pelo monitoramento do teor de nutrientes no perfil do solo e da capacidade de sodificação e salinização do resíduo. Verificou-se que o aumento das doses de soro aumentou a condutividade elétrica e a porcentagem de sódio trocável em 1,75 e 7,75 em relação à testemunha, mas não ocasionou o processo de sodificação e salinização do solo. Como o soro de leite é uma fonte significativa de potássio, seu uso no solo promoveu aumentos decrescentes na produtividade. Concluiu-se que o soro de leite nas doses utilizadas não causou sodificação ou salinização do solo. Este resíduo na dose segura pode ser utilizado como $\mathrm{K}$ e N. O soro de leite nas condições testadas não aumentou o crescimento da cultura.

Palavras-chave: Fertilidade. Oryza sativa. Resíduos orgânicos. Salinização. Sódio.

\section{References}

AlencAR, T. A. S.; TAVARES, A. T.; CHAVES, P. P. N.; FERREIRA, T. A.; NASCIMENTO, I. R. Efeito de intervalos de aplicação de urina bovina na produção de alface em cultivo protegido. Revista Verde, Mossoró, v. 7, n. 3, p. 53-67, 2012.

ALVES, M. P.; MOREIRA, R. O. M.; RODRIGUES JÚNIOR, R. H.; MARTINS, M. C. F.; PERRONE, I. T.; CARVALHO, A. F. Soro de leite: tecnologias para o processamento de coprodutos. Revista do Instituto de Laticínios Cândido Tostes, Juiz de Fora, v. 69, p. 212, 2014

BRASIL. Ministério de Agricultura, Pecuária e Abastecimento. Relatórios de produtos por UF. Brasília, DF, 2017. 
CAMPOS, H. Estatística experimental não paramétrica. Piracicaba: Ed. ESALQ, 349 p, 1983.

CRUZ, C. D. GENES: a software package for analysis in experimental statistics and quantitative genetics. Acta Scientiarum, Maringá, v. 35, n. 3, p. 271-276, 2013.

DIAS, A. F. S.; SILVA, F. N.; MAIA, S. S. S. Resposta do arroz de sequeiro à adubação com NPK em solos do município de Ji-Paraná/Rondônia. Revista Verde de Agroecologia e Desenvolvimento Sustentável, Mossoró, v. 5, p. 120-124, 2010.

EMBRAPA - Empresa Brasileira de Pesquisa Agropecuária. Sistema Brasileiro de Classificação de Solos. Brasília, 353 p., 2013.

EMBRAPA - Empresa Brasileira de Pesquisa Agropecuária. Centro Nacional de Pesquisa de Solos. Manual de Métodos de Análise do Solo. 2. ed. Rio de Janeiro, 1997. 247 p.

FERREIRA, D. F. Sisvar: a computer statistical analysis system. Ciência e Agrotecnologia, Lavras, v. 35, n. 6, p. 1039-1042, 2011.

FRENKEL, H.; GOERTZEN, J. O.; RHOADES, J. D. Effects of clay type and content, exchangeable sodium percentage, and electrolyte concentration on clay dispersion and soil hydraulic conductivity. Soil Science Society America Journal, Madison, v. 42, n. 1, p. 32-39, 1978.

HOMEM, B. G. C.; ALMEIDA NETO, O. B. de.; SANTIAGO, A. M. F.; SOUZA, G. H. Dispersão da argila provocada pela fertirrigação com águas residuárias de criatórios de animais. Revista Brasileira de Agropecuária Sustentável, v. 2, p. 89-98, 2012.

IRRI - International Rice Researchlnstitute. Standard evaluation system for rice. Manila, 52 p., 1996.

MANTOVANI, J. R.; CARRERA, C.; LANDGRAF, P. R. C.; MIRANDA, J. M. Soro ácido de leite como fonte de nutrientes para o milho. Revista Brasileira Engenharia Agrícola e Ambiental, Campina Grande, v. 19, n. 4, p. 324-329, 2015.

MATOS, A. T.; ALMEIDA NETO, O. B.; MATOS, M. P. Saturação do complexo de troca de solos oxídicos com sódio. Revista Brasileira de Engenharia Agrícola e Ambiental, Campina Grande, v. 18 , n. 5 , p. 501-506, 2014.

MELO, R. F.; FERREIRA, P. A.; MATOS, A. T.; RUIZ, H. A.; OLIVEIRA, L. B. Deslocamento miscível de cátions básicos provenientes da água residuária de mandioca em colunas de solo. Revista Brasileira de Engenharia Agrícola e Ambiental. [online]. v. 10, n. 2, p. 456-465, 2006.

MORRILL, W. B. B.; ROLIM, M. M., BEZERRA NETO, E.; PEDROSA, E. M. R.; OLIVEIRA, V. S.; ALMEIDA, G. L. P. Produção e nutrientes minerais de milheto forrageiro e sorgo sudão adubado com soro de leite. Revista Brasileira Engenharia Agrícola e Ambiental, Campina Grande, v. 16, n. 2, p. 182-188, 2012.

RAIJ, B. V. Fertilidade do solo e manejo dos nutrientes. Piracicaba: International Plant Nutrition Institute, 2011. 
RICHARDS, L. A. Diagnosis and improvement of saline and alkali soils. Washington: United States Salinity Laboratory, 160 p, 1954.

SILVA, R. O. P. Aspectos das importações de soro de leite no Brasil: análise e indicadores do agronegócio. Análises e Indicadores do Agronegócio, São Paulo, v. 8, n. 7, p. 1-7, 2018.

SIQUEIRA, A. M. O.; MACHADO, E. C. L.; STAMFORD, T. L. M. Bebidas lácteas com soro de queijo e frutas. Ciência Rural, Santa Maria, v. 43, n. 9, p. 1693-1700, 2013.

SOUZA, D. M. G.; LOBATO, E.; REIN, T. A. Adubação com fósforo. In: SOUSA, D. M. G. de; LOBATO, E. (Ed.). Cerrado: correção do solo e adubação. 2. ed. Brasília, DF: Embrapa Informação Tecnológica, p. 147-167, 2004.

TIVET, F.; PINHEIRO, B. S.; RAÏSSAC, M.; DINGKUHN, M. Leaf blade dimensions of rice (Oryza sativa L. and Oryza glaberrima Steud.) relationships between tillers and the main stem. Annals of Botany, London, v. 88, p. 507-511, 2001.

VILLAR, M. L. P. Manual de interpretação de análise de plantas e solos e recomendação de adubação. Cuiabá: EMPAER-MT, 182 p., 2007.

ZAVAREZE, E. R.; MORAES, K. S.; SALAS-MELLADO, M. L M. Qualidade tecnológica e sensorial de bolos elaborados com soro de leite. Ciência e Tecnologia Alimentos, Campinas, v. 30, n. 1, p. 100-105, 2010.

Received: September 27, 2020

Accepted: January 19, 2021 